\title{
DNA Markers for Selection of Late Blight Resistant Potato Breeding Lines
}

\author{
Shaohua Chen 1,4, Tudor Borza1, Bohyun Byun', Robert Coffin², Joyce Coffin², Rick Peters³, \\ Gefu Wang-Pruski ${ }^{*}$
}

${ }^{1}$ Department of Plant, Food, and Environmental Sciences, Faculty of Agriculture, Dalhousie University, Truro, Canada

${ }^{2}$ Privar Farm Inc., North Wiltshire, Canada

${ }^{3}$ Agriculture and Agri-Food Canada, Charlottetown Research and Development Centre, Charlottetown, Canada

${ }^{4}$ Fujian Agriculture and Forestry University, Fuzhou, China

Email: *gefu.wang-pruski@dal.ca

How to cite this paper: Chen, S.H., Borza, T., Byun, B., Coffin, R., Coffin, J., Peters, R. and Wang-Pruski, G. (2017) DNA Markers for Selection of Late Blight Resistant Potato Breeding Lines. American Journal of Plant Sciences, 8, 1197-1209.

https://doi.org/10.4236/ajps.2017.86079

Received: December 30, 2017

Accepted: May 8, 2017

Published: May 11, 2017

Copyright $(9) 2017$ by authors and Scientific Research Publishing Inc. This work is licensed under the Creative Commons Attribution International License (CC BY 4.0).

http://creativecommons.org/licenses/by/4.0/ (c) (i) Open Access

\begin{abstract}
Potato late blight, caused by the oomycete Phytophthora infestans, is one of the most devastating diseases in the agricultural sector around the world. Many genes ( $R$ genes) conferring resistance to late blight have been identified in various potato species and most of these $R$ genes have been used in potato breeding. The aim of this study was to develop and validate PCR-based assays for the $R$ genes Rpi-blb1, Rpi-blb2, Rpi-blb3 and Rpi-bt1, to distinguish between late blight resistant and late blight susceptible potato progeny in the given breeding background. A total of 100 breeding progeny were screened for the presence of these $R$ genes and tested for resistance against $P$. infestans mating type A2, genotype US- 8 strain, using detached leaf and tuber rot assays. PCR products for the Rpi-blb1 and Rpi-bt1 resistance genes were identified in the resistant progeny but were absent in the susceptible ones; therefore these PCR assays could differentiate between late blight resistant and susceptible plants. Genotypic data from the DNA markers derived from the Rpi-blb1 and Rpi-bt1 genes was found to correlate with the phenotypic data for foliar late blight but not with data for tuber rot. Our results demonstrate that markers derived from these two $R$ genes could be useful for marker-assisted selection (MAS) for foliar late blight resistance in potato breeding programs.
\end{abstract}

\section{Keywords}

Late Blight, Phytophthora infestans, Resistance $R$ genes, DNA Markers

\section{Introduction}

Late blight, caused by the pathogen Phytophthora infestans (Mont.) de Bary, is the most destructive disease of cultivated potato (Solanum tuberosum L.). This 
pathogen is a diploid, heterothallic fungus-like oomycete with two mating types (A1 and A2). Severe losses have occurred due to late blight of potato in the agricultural sector in North America [1] and worldwide [2] if fungicides are not used for its control during the growing season. Moreover, new, more aggressive strains of $P$. infestans can be generated by sexual recombination when both mating types are present in a production area. The common A2 mating type, genotype US-8 strain that was predominantly found in Atlantic Canada in the past ten years has been recently replaced by new A1 mating types, including genotype US-23 and US-24 strains [3]. The occurrence of new strains adds new challenges to potato disease management, because of the potential risk that the new strains will show increased pathogenicity and resistance to currently used fungicides.

Breeding broad-spectrum disease resistance $(R)$ genes into potato cultivars is the best approach to protect potato crops from late blight. Eleven $R$ genes, named $R 1-R 11$ identified from wild Mexican hexaploid species Solanum demissum $(2 \mathrm{n}=6 \mathrm{x}=72)$, have been introgressed in different potato cultivars in the previous century [4]. However, P. infestans was able to overcome the resistance conferred by these $R$ genes [5]. Breeding programs have also used resistance genes derived from other wild species, such as $S$. bulbocastanum $(2 \mathrm{n}=2 \mathrm{x}$ $=24)$ which contains several $R$ genes [6]. Rpi-blb1 gene, also known as $R B$ gene, is located on chromosome 8 and was found to confer broad spectrum resistance against $P$. infestans when introduced into potatoes [7] [8]. A total of 63 resistance genes to $P$. infestans have been identified from various Solanum species and more than 25 have been localized on the potato genome map [9] and cloned [10]. The majority of $R$ genes contain Leucine-rich repeat (LRR) and nucleotide binding site (NBS) domains and are able to specifically recognize cytoplasmic effectors of the pathogen [11].

The efficiency of potato breeding for late blight resistance can be improved with the help of molecular markers tightly linked to the resistance genes [12] [13]. To date, QTL for late blight resistance have been reported on almost every potato chromosome and in many cases the same region of the genome also contains clusters of resistance $R$ genes [14], thus $R$ genes are candidates for the QTL effect. The "candidate gene approach" enables the identification of DNA markers highly useful for marker-assisted selection (MAS) in potato breeding. The goal of the present study was to 1) test and develop DNA markers to distinguish between late blight resistant and susceptible plants; 2) use these markers to screen the breeding progeny, and 3) correlate genotypic results with phenotype data, obtained from detached leaf infection and tuber rot infection assays, to confirm the PCR-based screening results. Such information contributes to the development of more reliable screening methods for potato breeding programs focused on the development of late blight resistance.

\section{Materials and Methods}

This study was carried out in two phases. In the first phase, several PCR-based 
assays for four potato $R$ genes conferring resistance to late blight were either tested or developed. In the second phase, the DNA markers for these $R$ genes, generated by PCR, were used to screen the resistant lines in a breeding population, and resistance was confirmed by detached leaf infection assay and tuber rot analysis.

\subsection{Primer Design and Selection}

In this study, four P. infestans resistance genes named Rpi-blb1 [8], Rpi-blb2 [15], Rpi-blb3 [16] and Rpi-bt1 [17] were used based on prior publications. Based on the DNA sequences of the four candidate genes, a total of 24 genespecific primer pairs were selected; 15 primers were based on publications [6] [8] [15] [16] [18] [19] and 9 primers were designed in our laboratory using Primer3 online tool (http://biotools.umassmed.edu/bioapps/primer3_www.cgi). The primer pairs used to amplify the four resistance $R$ genes are listed in Table 1 .

\subsection{Plant Materials}

The parental clones examined in these experiments were F02005, F02006, Prospect and PR90-50-32. F02005 and F02006 parental clones are resistant to $P$. infestans and were developed by Agriculture and Agri-Food Canada, Fredericton, New Brunswick. Prospect and PR90-50-32 are susceptible to $P$. infestans and were developed by Privar Farm Inc., Prince Edward Island. PR90-50-32 is a sibling of the variety Prospect that was selected from a cross between Shepody and Russette [20]. The resistant parents F02005 and F02006 were descended from J101K27 which was derived from a cross between J101 and Katahdin (provided by Dr. John Helgeson, Madison, WI). J101 (6x) was developed from a somatic fusion between $S$. bulbocastanum (2x) and $S$. tuberosum $(4 \mathrm{x}) . S$. bulbocastanum is a wild potato variety that is resistant to $P$. infestans and was likely a source of the resistance genes [6]. Genomic DNA from the four parental clones was used to verify the PCR-based markers (Table 1). After the PCR approach confirmed that these DNA markers are strongly associated with resistance to late blight, they were further tested in 9 selected progeny that have been shown to be resistant to $P$. infestans US- 8 strain. The PCR markers were finally used to screen 100 progeny from the cross between F02005 and PR90-50-32. The breeding parents and the 9 selected clones resistant to late blight were grown in the experimental field of Privar Farms, in Prince Edward Island, while the 100 progeny were grown in a greenhouse, on the Agricultural Campus of Dalhousie University.

\subsection{Genomic DNA Extraction and PCR}

DNA was extracted from frozen leaves using the CTAB plant genomic extractionmethod as described [21]. PCR amplification reactions were carried out in $25 \mu \mathrm{L}$ reaction mixture containing $1 \times$ Crimson Taq Reaction Buffer, $200 \mu \mathrm{M}$ of each dNTP, $200 \mathrm{nM}$ primers, $100 \mathrm{ng}$ of template DNA and $0.025 \mathrm{U}$ Crimson Taq 
Table 1. PCR primer pairs designed to detect four $R$ genes in the potato genome and results obtained using PCR assays of the four parental clones.

\begin{tabular}{|c|c|c|c|c|c|c|c|c|c|}
\hline Marker & $\begin{array}{l}\text { Primer } \\
\text { pair } \\
\text { name }\end{array}$ & $R$ Gene & Primers $5^{\prime} \rightarrow 3^{\prime}$ & $\begin{array}{c}\text { Annealing } \\
\text { Temperature } \\
\text { (Tm) }\end{array}$ & Reference & $\begin{array}{c}\text { F02005 } \\
\text { (R) }\end{array}$ & $\begin{array}{l}\text { F02006 } \\
\text { (R) }\end{array}$ & $\begin{array}{l}\text { Prospect } \\
\text { (S) }\end{array}$ & $\begin{array}{l}\text { PR90-50-32 } \\
\text { (S) }\end{array}$ \\
\hline 1 & $\begin{array}{l}\text { BLB1F/ } \\
\text { BLB1R }\end{array}$ & Rpi-blb1 & $\begin{array}{l}\text { F: AACCTGTATGGCAGTGGCATG } \\
\text { R: GTCAGAAAAGGGCACTCGTG }\end{array}$ & 58 & [18] & + & + & - & - \\
\hline 2 & $1 / 1^{\prime}$ & $R p i-b l b 1$ & $\begin{array}{l}\text { F: CACGAGTGCCCTTTTCTGAC } \\
\text { R: ACAATTGAATTTTTAGACTT }\end{array}$ & 50 & [19] & - & - & - & - \\
\hline 3 & $1521 / 518$ & $R p i-b l b 1$ & $\begin{array}{l}\text { F: GAAAGTCTAGAGTTACACTGG } \\
\text { R: CAATCACAATGGCAGGAACC }\end{array}$ & 58 & [18] & + & + & - & - \\
\hline 4 & $517 / 1519$ & $R p i-b l b 1$ & $\begin{array}{l}\text { F: CATTCCAACTAGCCATCTTGG } \\
\text { R: TATTCAGATCGAAAGTACAACG }\end{array}$ & 58 & [18] & + & + & - & - \\
\hline 5 & $\begin{array}{l}\text { BLB1F1/ } \\
\text { BLB1R1 }\end{array}$ & Rpi-blb1 & $\begin{array}{l}\text { F: GWGMATGGGAACATGTGAGAGC } \\
\text { R: GYTGTTAGGTGCTGCAATCC }\end{array}$ & 55 & [18] & + & + & + & + \\
\hline 6 & $\begin{array}{l}\text { RGA1F/ } \\
\text { RGA1R }\end{array}$ & Rpi-blb1 & $\begin{array}{l}\text { F: CAGTCACTTTCTTGTTTGCCG } \\
\text { R: CAGTAGTGAAGTCACTGTGTG }\end{array}$ & 55 & [18] & + & + & + & + \\
\hline 7 & $\begin{array}{l}\text { CT88F1/ } \\
\text { CT88R }\end{array}$ & $R p i-b l b 1$ & $\begin{array}{l}\text { F: TTCAAGAGCTTGAAGACATAACA } \\
\text { R: ATGGCGTGATACAATCCGAG }\end{array}$ & 60 & [8] & + & + & + & + \\
\hline 8 & $\begin{array}{l}\text { BLB1F1/ } \\
\text { BLB1R }\end{array}$ & $R p i-b l b 1$ & $\begin{array}{l}\text { F: GWGMATGGGAACATGTGAGAGC } \\
\text { R: GTCAGAAAAGGGCACTCGTG }\end{array}$ & 55 & [18] & + & + & - & - \\
\hline 9 & $\begin{array}{l}\text { BLB1F/ } \\
\text { BLB1R1 }\end{array}$ & Rpi-blb1 & $\begin{array}{l}\text { F: AACCTGTATGGCAGTGGCATG } \\
\text { R: GYTGTTAGGTGCTGCAATCC }\end{array}$ & 55 & [18] & + & + & + & + \\
\hline 10 & $\begin{array}{l}\mathrm{BLB} 2 \mathrm{~F} / \\
\mathrm{BLB} 2 \mathrm{R}\end{array}$ & Rpi-blb2 & $\begin{array}{l}\text { F: GGACTGGGTAACGACAATCC } \\
\text { R: GCATTAGGGGAACTCGTGCT }\end{array}$ & 58 & [18] & - & - & - & - \\
\hline 11 & $\begin{array}{l}\text { BLB2F1/ } \\
\text { BLB2R1 }\end{array}$ & Rpi-blb2 & $\begin{array}{l}\text { F: ATTGCTGGARTCATTGCTGG } \\
\text { R: ATTTATGGCTGCAGAGGACC }\end{array}$ & 55 & [18] & + & + & + & + \\
\hline 12 & $\begin{array}{l}\text { BLB2F1/ } \\
\text { BLB2R }\end{array}$ & Rpi-blb2 & $\begin{array}{l}\text { F: ATTGCTGGARTCATTGCTGG } \\
\text { R: GCATTAGGGGAACTCGTGCT }\end{array}$ & 55 & [18] & ND & ND & ND & ND \\
\hline 13 & $\begin{array}{l}\mathrm{BLB} 2 \mathrm{~F} / \\
\mathrm{BLB} 2 \mathrm{R} 1\end{array}$ & Rpi-blb2 & $\begin{array}{l}\text { F: GGACTGGGTAACGACAATCC } \\
\text { R: ATTTATGGCTGCAGAGGACC }\end{array}$ & 55 & [18] & ND & ND & ND & ND \\
\hline 14 & $\begin{array}{l}\text { 14L24LF/ } \\
14 \mathrm{~L} 24 \mathrm{LR}\end{array}$ & Rpi-blb2 & $\begin{array}{l}\text { F: AGAAAGCTCACCAGTGGACC } \\
\text { R: ATTTATGGCTGCAGAGGACC }\end{array}$ & 60 & [15] & + & + & + & + \\
\hline 15 & $\begin{array}{l}\mathrm{BLB} 2 \mathrm{Fa} / \\
\mathrm{BLB} 2 \mathrm{Ra}\end{array}$ & Rpi-blb2 & $\begin{array}{l}\text { F: TGTCTTTCTCAAACCTCTGG } \\
\text { R: AGTGAATCGGATGTCAGAGG }\end{array}$ & 55 & This study & + & + & + & + \\
\hline 16 & $\begin{array}{l}\text { BLB3Fa/ } \\
\text { BLB3Rb }\end{array}$ & Rpi-blb3 & $\begin{array}{l}\text { F: GTCCAAGAAGCCACTCCATA } \\
\text { R: CAGGGTCAACATCTTTCCAC }\end{array}$ & 54 & This study & + & + & + & + \\
\hline 17 & $\begin{array}{l}\mathrm{BLB} 3 \mathrm{Fb} / \\
\mathrm{BLB} 3 \mathrm{R}\end{array}$ & Rpi-blb3 & $\begin{array}{l}\text { F: TGTCGCTGAAAGAGTAGRCS } \\
\text { R: TATGGAGTGGCTTCTTGAAC }\end{array}$ & 54 & This study & - & - & - & - \\
\hline 18 & $\begin{array}{l}\mathrm{BLB} 3 \mathrm{Fa} / \\
\mathrm{BLB} 3 \mathrm{Rc}\end{array}$ & Rpi-blb3 & $\begin{array}{l}\text { F: GTCCAAGAAGCCACTCCATA } \\
\text { R: CAGSGTCAACATCTTTCCAC }\end{array}$ & 54 & This study & + & + & + & + \\
\hline 19 & $\begin{array}{l}\mathrm{BLB} 3 \mathrm{~F} / \\
\mathrm{BLB} 3 \mathrm{R}\end{array}$ & Rpi-blb3 & $\begin{array}{l}\text { F: TGTCGCTGAAAGAGTAGGCC } \\
\text { R: TATGGAGTGGCTTCTTGAAC }\end{array}$ & 50 & [6] & + & + & + & + \\
\hline 20 & $\begin{array}{l}\mathrm{BLB} 3 \mathrm{~F} / \\
\mathrm{BLB} 3 \mathrm{Ra}\end{array}$ & Rpi-blb3 & $\begin{array}{l}\text { F: TGTCGCTGAAAGAGTAGGCC } \\
\text { R: TCCTGAGGTTTATATGACTCATC }\end{array}$ & 50 & [6] & - & - & - & - \\
\hline 21 & $\begin{array}{l}\text { Th21F/ } \\
\text { Th21R }\end{array}$ & Rpi-blb3 & $\begin{array}{l}\text { F: ATTCAAAATTCTAGTTCCGCC } \\
\text { R: AACGGCAAAAAAGCACCAC }\end{array}$ & 56 & [16] & - & - & - & - \\
\hline 22 & $\begin{array}{l}\mathrm{BT} 1 \mathrm{~F} / \\
\mathrm{BT} 1 \mathrm{R}\end{array}$ & Rpi-bt1 & $\begin{array}{l}\text { F: CTACATGGCTGTCATTCACT } \\
\text { R: CATAGGGCAACATTTAATCTC }\end{array}$ & 53 & This study & + & + & - & - \\
\hline 23 & $\begin{array}{l}\text { BT1F1/ } \\
\text { BT1R1 }\end{array}$ & $R p i-b t 1$ & $\begin{array}{l}\text { F: GAGATTAAATGTTGCCCTATG } \\
\text { R: GTTGGACAAAACTCAACTGAT }\end{array}$ & 53 & This study & + & + & - & - \\
\hline 24 & $\begin{array}{l}\mathrm{BT} 1 \mathrm{~F} / \\
\mathrm{BT} 1 \mathrm{R} 1\end{array}$ & $R p i-b t 1$ & $\begin{array}{l}\text { F: CTACATGGCTGTCATTCACT } \\
\text { R: GTTGGACAAAACTCAACTGAT }\end{array}$ & 53 & This study & + & + & - & - \\
\hline
\end{tabular}

+: amplified, -: not amplified, ND: not determined. 
Table 2. DNA marker assisted screening using the primer pair 1 and primer pair 22 for $R p i$-blb1 and Rpi-bt1 genes, respectively. When a primer pair generated expected PCR products, the progeny was marked as ' + ', indicating the presence of the $R$ genes. When a primer pair failed to generate the expected PCR products, the progeny was marked as ' - ', indicating the absence of the $R$ genes.

\begin{tabular}{ccccc}
\hline Sample \# & Clone code & Cross combinations & Rpi-blb1 & Rpi-bt1 \\
\hline $\mathbf{1}$ & F02005 & Resistant parent & + & + \\
$\mathbf{2}$ & F02006 & Resistant parent & - & - \\
$\mathbf{3}$ & Prospect & Susceptible parent & - & + \\
$\mathbf{4}$ & PR90-50-32 & Susceptible parent & + & + \\
$\mathbf{5}$ & $08-101-04$ & F02005 x Prospect & - & - \\
$\mathbf{6}$ & $09-101-03$ & F02005 x Prospect & - & - \\
$\mathbf{7}$ & $09-101-06$ & F02005 x Prospect & + & + \\
$\mathbf{8}$ & $10-100-01$ & F02006 x Prospect & + \\
$\mathbf{9}$ & $10-100-02$ & F02006 x Prospect & + \\
$\mathbf{1 0}$ & $10-100-03$ & F02006 x Prospect & + \\
$\mathbf{1 1}$ & $09-102-06$ & F02005 x PR90-50-32 & + \\
$\mathbf{1 2}$ & $09-102-03$ & F02006 x PR90-50-32 & + \\
+
\end{tabular}

+ : indicating the presence of the $R$ genes, -: indicating the absence of the $R$ genes.

Table 3. DNA marker assisted screening (presence or absence of Rpi-blb1 and Rpi-bt1 genes) of 100 progeny and subsequent detached leaf assay.

\begin{tabular}{|c|c|c|c|c|}
\hline Tests & $\begin{array}{c}\text { Number } \\
\text { of clones tested }\end{array}$ & $\begin{array}{c}\text { Presence of both } \\
R p i-b l b 1 \text { and } R p i-b t 1\end{array}$ & $\begin{array}{l}\text { Presence } \\
\text { of } R p i-b t 1\end{array}$ & $\begin{array}{c}\text { Absence of both } \\
R p i-b l b 1 \text { and Rpi-bt1 }\end{array}$ \\
\hline & 100 & 45 & 6 & 49 \\
\hline $\begin{array}{l}\text { Gene } \\
\text { specific } \\
\text { primers } \\
\text { identification }\end{array}$ & & $\begin{array}{c}(2,6,7,8,9,10,11,13,16,20, \\
21,24,26,29,31,32,33,35,38, \\
39,41,43,5557,59,64,66,68, \\
70,73,74,76,78,79,80,81,83, \\
85,88,91,92,95,96,98,100)\end{array}$ & $(27,28,47,56,58,65)$ & $\begin{array}{c}(1,4,5,12,14,15,17,18,19, \\
22,23,25,30,34,36,37,40, \\
42,44,45,46,48,49,51,52, \\
53,54,61,62,63,67,69,71 \\
72,75,77,82,84,86,87,89 \\
90,93,94,97,99,101,102,103)\end{array}$ \\
\hline $\begin{array}{l}\text { Detached } \\
\text { leaf assay }\end{array}$ & 100 & $\begin{array}{l}39 \text { Resistant } \\
\text { (leaves had high resistance on both } 4 \text { and } 7 \text { DPI) } \\
\text { and } 6 \text { moderate resistant } \\
\text { (leaves showed some resistance on } 7 \text { DPI) }\end{array}$ & $\begin{array}{l}6 \text { Moderate Resistant } \\
\text { (leaves showed some } \\
\text { resistance on } 7 \text { DPI ) }\end{array}$ & $\begin{array}{c}49 \text { Susceptible } \\
\text { (Leaves were highly } \\
\text { susceptible on both } 4 \text { and } 7 \text { DPI) }\end{array}$ \\
\hline
\end{tabular}

polymerase (New England Biolabs, Pickering, Ontario, CA). Thermocycling program was conducted in a Bio-Rad iCycler Thermal Cycler at $95^{\circ} \mathrm{C}$ for $30 \mathrm{~s}$ as the initial denaturation step, 30 cycles at $95^{\circ} \mathrm{C}$ for $30 \mathrm{~s}$, at $55^{\circ} \mathrm{C}$ for $30 \mathrm{~s}$, at $68^{\circ} \mathrm{C}$ for $1 \mathrm{~min}$ followed by a final extension step at $68^{\circ} \mathrm{C}$ for $5 \mathrm{~min}$. Amplified PCR products were detected on a $0.8 \%$ agarose gel stained in $1 \mathrm{x}$ Tris-acetate EDTA buffer with GelRed (Biotium ${ }^{\text {six }}$, Hayward, CA) and visualized on a UV transilluminator. 


\subsection{Detached Leaf Infection Assay and Tuber Infection Assay}

The true seeds of the 100 progeny from the F02005 and PR90-50-32 cross were planted in growth chambers for mini tuber production. Mini tubers were then planted in a greenhouse using a cycle of $16 \mathrm{~h}$ of light at $24^{\circ} \mathrm{C}$ followed by $8 \mathrm{~h}$ of dark at $16^{\circ} \mathrm{C}$ with $6 \mathrm{~h} / \mathrm{d}$ photoperiod $\left(100 \mu \mathrm{m} \cdot \mathrm{m}^{-1} \cdot \mathrm{s}^{-1}\right)$ and leaves from these plants were used for the detached leaf infection assay. The tubers harvested at the end of the growing season were used for tuber rot evaluation. Detached leaf infection assay [22] was performed for all 100 individuals using $P$. infestans mating type A2, genotype US- 8 . Each leaf was placed in a Petri dish $(15 \mathrm{~cm}$ in diameter) and inoculated with approximately 50,000 sporangia, applied on both sides of the leaf. One leaf was used for each clone and assessment of infection was done 4 and 7 days post infection (DPI). In the tuber rot experiment, a total of 316 tubers from 81 progeny were tested for resistance to tuber rot caused by $P$. infestans. The other 19 progeny did not produce tubers. The number of tubers analyzed from each clone varied from 1 to 6 with an average number of 3.9 tubers per progeny.

\section{Results and Discussion}

\subsection{Identification of PCR Markers for the $R$ Genes}

Twenty-four gene-specific primer pairs were selected or designed to determine whether the four candidate $R$ genes, Rpi-blb1, Rpi-blb2, Rpi-blb3 and Rpi-bt1, were present or absent in the resistant (R) clones F02005 and F02006 and the susceptible (S) clones Prospect and PR90-50-32 (Table 1). PCR products for the Rpi-blb1 gene, amplified using primers 1, 3, 4 and 8 showed clear polymorphism between the $\mathrm{R}$ and S clones. The primer pairs 22, 23 and 24 for the Rpi-bt1 gene also showed polymorphic PCR patterns between the R and S clones (Table 1). In terms of the Rpi-blb2 and Rpi-blb3 genes, the PCR results obtained from all the primer pairs (10-21, Table 1 ) did not show any polymorphism between the R and $S$ clones. The results of PCR amplification for all four genes in resistant (R) and susceptible ( $\mathrm{S}$ ) clones using the 24 gene-specific primers are summarized in Table 1.

Based on these results, we can conclude that the Rpi-blb1 and Rpi-bt1 genes are responsible for the resistance to $P$. infestans in the F02005 and F02006 parental plants, therefore, these polymorphic PCR products could be used as DNA markers to distinguish $\mathrm{R}$ progeny from $\mathrm{S}$ progeny generated by breeding these parental plants. Two of these seven PCR primer pairs (Markers 1 and 22, Table 1 ) were selected to amplify the two $R$ genes (Rpi-blb1 and Rpi-bt1) in all subsequent studies.

The primer sequences for these two $R$ genes are:

Primer pair 1: F 5'- AACCTGTATGGCAGTGGCATG-3';

R 5'- GTCAGAAAAGGGCACTCGTG-3' [18];

Primer pair 22: F 5'- CTACATGGCTGTCATTCACT-3';

R 5'- CATAGGGCAACATTTAATCTC-3'.

These two PCR markers were further validated by using the 4 parents and the 9 
offspring that showed moderate resistance to late blight based on previous pathogen infection experiments (Table 2). Specific bands of $820 \mathrm{bp}$ and $729 \mathrm{bp}$ were identified using Marker 1 and Marker 22, respectively, in the resistant parents; these bands were absent in susceptible clones. The example of the PCR products using Marker 1 in an agarose gel is shown in Supplementary Figure S1. The DNA markers generated using these primer pairs accurately detected the four parents (Table 2). From the 9 progeny tested, 7 of them (Samples 5, 8, 9, 10,11, 12, and 13) contained the two $R$ genes, and are shown as ' + ' in Table 2. Two progeny, samples 6 and 7, tested negative for the presence of the two $R$ genes in their genome (shown as '-' in Table 2). Therefore, these two progeny that were initially screened as resistant in the late blight infection experiment may have resistance to late blight conferred by other $R$ genes not characterized so far in $S$. bulbocastanum.

\subsection{Screening a Breeding Population Using the PCR Markers}

A total of 100 progeny from the cross between F02005 (R) and PR90-50-32 (S) were evaluated for the presence or absence of the two $R$ genes. Marker 1 and 22 were used and PCR was performed for all of the 100 progeny (Supplementary Figure S2). Based on the PCR results, these 100 progeny were categorized into three groups. The first group of 45 progeny contained both genes, the second group of 6 progeny contained only the Rpi-bt1 gene, while in the remaining 49 progeny, both genes were absent (Table 3 ). Table 3 lists the clone numbers in each of the three groups. In order to determine which progeny in these three groups possessed resistance to late blight, detached leaf infection and tuber infection assays were carried out.

\subsection{Detached Leaf Infection Assay}

The detached leaf infection assay was performed for all 100 samples. Infection results from 4 DPI and 7 DPI were quantified in two ways: 1) the percentage of infected foliar area (examples of leaves at 4 and 7 DPI are shown in Figure 1);2) the percentage of foliar area covered with sporangiophores and sporangia (data not shown). As shown in Table 3, 39 out of the 45 clones in Group 1, that tested positive for both Rpi-blb1 and Rpi-bt1 genes, were found to be resistant to late blight. A total of 11 clones showed moderate resistance (leaf lesions were visible 7 DPI) to late blight. Of these 11 clones, 6 were from Group 2, thereby possessing only the Rpi-bt1 gene. All 49 clones that tested negative in the PCR assays, indicating that both Rpi-blb1 and Rpi-bt1 genes were missing from their genomes (Group 3), were found to be susceptible to late blight. It is worth mentioning that at 7 DPI, only 22 resistant individuals from the 45 clones in Group 1 showed no sporangial production on their leaves. These individuals were considered to be extremely resistant to late blight.

\subsection{Tuber Rot Analysis}

Previous studies using various potato varieties have shown that the expression of $R$ genes may be different in leaves and tubers [23] [24]. The presence of major 
$4 \mathrm{DPI}$
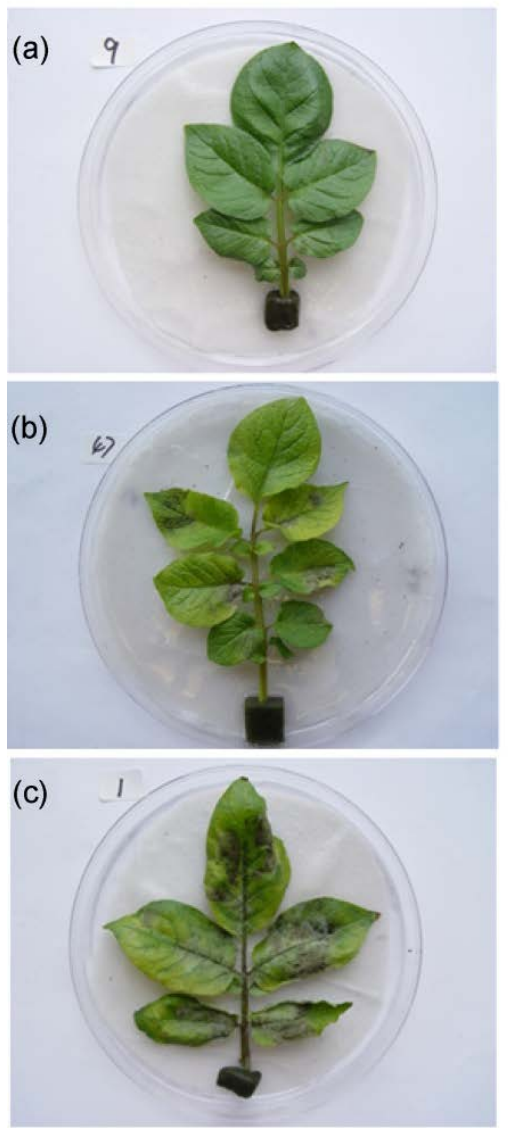

$7 \mathrm{DPI}$
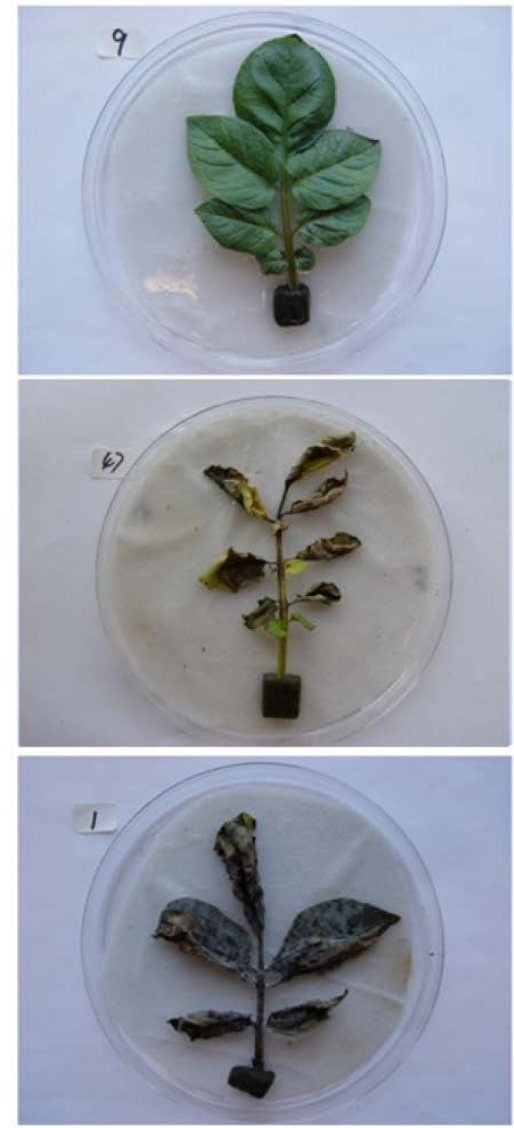

Figure 1. Evaluation of detached leaf assay 4 and 7 days after inoculation with $P$. infestans sporangia. a) Clone 9 a resistant phenotype that possessed both genes (Rpi-blb1 and Rpi-bt1); b) clone 47 showing moderate resistance, where lesions were visible at 7 DPI; c) clone 1 in which both genes were absent showing a susceptible phenotype.

resistance $(R)$ genes has been shown to increase resistance to foliar late blight infection in many potato cultivars [6] [14] [15] [16] [17] [18] [25] [26]. To assess this relationship in the breeding progeny analyzed in this study, the levels of resistance to tuber rot were also evaluated. From the 100 progeny grown under greenhouse conditions, 81 progeny generated a total of 316 tubers. These tubers were subsequently used for tuber rot analysis. Disease severity was assessed 20 DPI. Based on tuber infection severity, the 81 progeny were divided into three groups: Group 1 contained 14 clones that were highly resistant to late blight (disease severity $<20 \%$ ). Of these 14 clones, 10 contained both genes and were resistant to late blight in leaves. The other 4 clones did not possess either of the two genes analyzed. Their tuber resistance to late blight must come from other genetic factors. Group 2 contained 18 clones that showed medium resistance to late blight (disease severity between $20 \%-50 \%$ ). Of these 18 clones, only one clone possessed both genes associated with foliar late blight resistance. Group 3 contained the rest of the 49 clones that showed high susceptibility to tuber rot (disease severity $>50 \%$ ). Among the 49 susceptible clones, 24 clones possessed 
both $R$ genes, 3 clones had only $R p i-b t 1$ gene while 22 clones tested negative in the gene specific PCR assays. These results suggest that the Rpi-blb1 and Rpi-bt1 genes do not confer significant resistance to tuber rot and, therefore, are not suitable as DNA markers for assessing tuber resistance against $P$. infestans.

The two $R$ genes from the resistant parent F02005 segregated in the progeny with roughly half (45) of the individuals carrying both the Rpi-blb1 and Rpi-bt1 genes. Among the 45 clones, 10 of them, having both $R$ genes, showed strong resistance to late blight in leaves and tubers. A small number of individuals (6) had only one of the markers. Since these clones showed various levels of susceptibility to late blight in both leaves and in tubers, we can assume that the presence of both genes is required for a clone to possess high levels of resistance to late blight. The need for multiple potato $R$ genes to achieve strong resistance against several strains of $P$. infestans was suggested or demonstrated in several other studies [6] [26] [27] [28].

Correlation analyses between foliar late blight and tuber rot did not reveal a strong correlation among the three groups (data not shown). This suggests that the $R$ genes from $S$. bulbocastanum confer resistance against $P$. infestans in leaves but not in tubers. Halterman et al. [29] using several transgenic cultivars transformed with Rpi-blb1 (or RB gene) also reported that all transgenic lines had high levels of foliar resistance against $P$. infestans, but the tubers did not exhibit such traits. A possible explanation for these findings is that the expression of Rpi-blb1 and Rpi-bt1 in tubers is not high enough to provide adequate resistance against $P$. infestans. Indeed, it has been shown, in many cultivars, that resistance to late blight can be different in different parts of the plant, including leaf, stem and tubers [28] [30] [31]. Also, while some studies suggested that some $R$ genes in potato have the ability to confer both foliar and tuber resistance [32] [33] [34] [35], other studies suggested the opposite [36] [37]. Clearly, as mentioned before, multiple $R$ genes are essential for strong and durable resistance against late blight and this can be achieved only by obtaining, through classic breeding or by transgenic approaches, potato cultivars that harbor three or more such $R$ genes [6] [26] [27] [28].

In conclusion, this study showed that resistant parental lines derived from $S$. bulbocastanum that were used in the breeding program possessed in their genome the Rpi-blb1 and Rpi-bt1 genes which were transmitted to roughly half of the resulting progeny. These genes conferred good resistance against foliar late blight but not against tuber rot. The DNA markers derived from Rpi-blb1 and $R p i-b t 1$ genes were found to be useful to select breeding lines exhibiting resistance against $P$. infestans in potato leaves.

\section{Acknowledgements}

The authors would like to acknowledge the financial support from Privar Farm Inc. and the scholarship from the Chinese Scholar Council and Fujian Agriculture and Forestry University provided to Shaohua Chen as a visiting graduate student. 


\section{References}

[1] Guenthner, J., Michael, K. and Nolte, P. (2001) The Economic Impact of Potato Late Blight on US Growers. Potato Research, 44, 121-125. https://doi.org/10.1007/BF02410098

[2] Hijmans, R.J. (2003) The Effect of Climate Change on Global Potato Production. American Journal of Potato Research, 80, 271-279.

https://doi.org/10.1007/BF02855363

[3] Peters, R.D., Al-Mughrabi K.I., Kalischuk, M.L., Dobinson, K., Conn, K., Alkher, H., Islam, Md.R., Daayf, F., Lynn, J., Bizimungu, B., De Koeyer, D., Levesque, A. and Kawchuk, L.M. (2014) Migration and Recombination Increases Phytophthora infestans Population Diversity and Independent Segregation of Genotype Specific Loci. Canadian Journal of Plant Pathology, 36, 73-82. https://doi.org/10.1080/07060661.2014.892900

[4] Müller, K. and Black, W. (1952) Potato Breeding for Resistance to Blight and Virus Diseases during the Last Hundred Years. Zeitschrift für Pflanzenzüchtung, 31, 305318.

[5] Nelson, R.R. (1978) Genetics of Horizontal Resistance to Plant Diseases. Annual Review of Phytopathology, 16, 359-378. https://doi.org/10.1146/annurev.py.16.090178.002043

[6] Lokossou, A.A., Rietman, H., Wang, M., Krenek, P., van der Schoot, H., Henken, B., Hoekstra, R., Vleeshouwers, V.G., van der Vossen, E.A. and Visser, R.G. (2010) Diversity, Distribution, and Evolution of Solanum bulbocastanum Late Blight Resistance Genes. Molecular Plant-Microbe Interactions, 23, 1206-1216.

https://doi.org/10.1094/MPMI-23-9-1206

[7] Song, J., Bradeen, J.M., Naess, S.K., Raasch, J.A., Wielgus, S.M., Haberlach, G.T., Liu, J., Kuang, H., Austin-Phillips, S. and Buell, C.R. (2003) Gene RB Cloned from Solanum bulbocastanum Confers Broad Spectrum Resistance to Potato Late Blight. Proceedings of the National Academy of Sciences of the United States of America, 100, 9128-9133. https://doi.org/10.1073/pnas.1533501100

[8] Van Der Vossen, E., Sikkema, A., Hekkert, B.T.L., Gros, J., Stevens, P., Muskens, M., Wouters, D., Pereira, A., Stiekema, W. and Allefs, S. (2003) An ancient R Gene from the Wild Potato Species Solanum bulbocastanum Confers Broad-Spectrum Resistance to Phytophthora infestans in Cultivated Potato and Tomato. The Plant Journal, 36, 867-882. https://doi.org/10.1046/j.1365-313X.2003.01934.x

[9] Barone, A. (2004) Molecular Marker-Assisted Selection for Potato Breeding. American Journal of Potato Research, 81, 111-117. https://doi.org/10.1007/BF02853608

[10] Rodewald, J. and Trognitz, B. (2013) Solanum Resistance Genes against Phytophthora infestans and Their Corresponding Avirulence Genes. Molecular Plant Pathology, 14, 740-757. https://doi.org/10.1111/mpp.12036

[11] Meyers, B.C., Kozik, A., Griego, A., Kuang, H. and Michelmore, R.W. (2003) Genome-Wide Analysis of NBS-LRR-Encoding Genes in Arabidopsis. The Plant Cell, 15, 809-834. https://doi.org/10.1105/tpc.009308

[12] Bisognin, D.A. and Douches, D.S. (2002) Genetic Diversity in Diploid and Tetraploid Late Blight Resistant Potato Germplasm. HortScience, 37, 178-183.

[13] Pattanayak, D., Chakrabarti, S.K. and Naik, P.S. (2002) Genetic Diversity of Late Blight Resistant and Susceptible Indian Potato Cultivars Revealed by RAPD Markers. Euphytica, 128, 183-189. https://doi.org/10.1023/A:1020861225738

[14] Gebhardt, C. and Valkonen, J.P.T. (2001) Organization of Genes Controlling Disease Resistance in the Potato Genome. Annual Review of Phytopathology, 39, 79 - 
102. https://doi.org/10.1146/annurev.phyto.39.1.79

[15] Vossen, E.A., Gros, J., Sikkema, A., Muskens, M., Wouters, D., Wolters, P., Pereira, A. and Allefs, S. (2005) The Rpi-blb2 Gene from Solanum bulbocastanum Is an Mi-1 Gene Homolog Conferring Broad-Spectrum Late Blight Resistance in Potato. The Plant Journal, 44, 208-222. https://doi.org/10.1111/j.1365-313X.2005.02527.x

[16] Lokossou, A.A., Park, T.-H., van Arkel, G., Arens, M., Ruyter-Spira, C., Morales, J., Whisson, S.C., Birch, P.R., Visser, R.G. and Jacobsen, E. (2009) Exploiting Knowledge of $R / A v r$ Genes to Rapidly Clone a New LZ-NBS-LRR Family of Late Blight Resistance Genes from Potato Linkage Group IV. Molecular Plant-Microbe Interactions, 22, 630-641. https://doi.org/10.1094/MPMI-22-6-0630

[17] Oosumi, T., Rockhold, D., Maccree, M., Deahl, K., McCue, K. and Belknap, W. (2009) Gene Rpi-bt1 from Solanum bulbocastanum Confers Resistance to Late Blight in Transgenic Potatoes. American Journal of Potato Research, 86, 456-465. https://doi.org/10.1007/s12230-009-9100-4

[18] Wang, M., Allefs, S., van den Berg, R.G., Vleeshouwers, V.G., van der Vossen, E.A. and Vosman, B. (2008) Allele Mining in Solanum: Conserved Homologues of Rpi-blb1 Are Identified in Solanum stoloniferum. Theoretical and Applied Genetics, 116, 933-943. https://doi.org/10.1007/s00122-008-0725-3

[19] Colton, L.M., Groza, H.I., Wielgus, S.M. and Jiang, J. (2006) Marker-Assisted Selection for the Broad-Spectrum Potato Late Blight Resistance Conferred by Gene $R B$ Derived from a Wild Potato Species. Crop Science, 46, 589-594. https://doi.org/10.2135/cropsci2005.0112

[20] Coffin, J., Coffin, R., Thompson, A., Geisel, B., Hardy, W., Veenhuis-MacNeill, S., Arsenault, W. and Platt, H. (2009) Prospect, a New High Yielding Potato Variety with Resistance to Verticillium Fungus and "Sugar Ends", for Production of French Fries. American Journal of Potato Research, 86, 139.

[21] Doyle, J.J. (1990) Isolation of Plant DNA from Fresh Tissue. Focus, 12, 13-15.

[22] Lim, S., Borza, T., Peters, R.D., Coffin, R.H., Al-Mughrabi, K.I., Pinto, D.P. and Wang-Pruski, G. (2013) Proteomics Analysis Suggests Broad Functional Changes in Potato Leaves Triggered by Phosphites and a Complex Indirect Mode of Action against Phytophthora infestans. Journal of Proteomics, 93, 207-223.

[23] Skrabule, I., Zoteyeva, N., Mezaka, I., Vilcane, D. and Usele, G. (2011) The Adaptation of MAS for Late Blight Resistance Evaluation of Potato Breeding Material. Proceedings of the 13th EuroBlight Workshop, St. Petersburg, 9-12 October 2011, 179-186.

[24] Nyankanga, R.O., Olanya, O.M., Wien, H.C., El-Bedewy, R., Karinga, J. and Ojiambo, P.S. (2008) Development of Tuber Blight (Phytophthora infestans) on Potato Cultivars Based on in Vitro Assays and Field Evaluations. HortScience, 43, 1501-1508.

[25] Toxopeus, H. (1958) Some Notes on the Relations between Field Resistance to Phytophthora infestans in Leaves and Tubers and Ripening Time in Solanum tuberosum subsp. Tuberosum. Euphytica, 7, 123-130. https://doi.org/10.1007/BF00035725

[26] Kim, H.J., Lee, H.R., Jo, K.R., Mortazavian, S.M., Huigen, D.J., Evenhuis, B., Kessel, G., Visser, R.G., Jacobsen, E. and Vossen, J.H. (2012) Broad Spectrum Late Blight Resistance in Potato Differential Set Plants MaR8 and MaR9 Is Conferred by Multiple Stacked $R$ Genes. Theoretical and Applied Genetics, 124, 923-935. https://doi.org/10.1007/s00122-011-1757-7

[27] Zhu, S., Li, Y., Vossen, J.H., Visser, R.G. and Jacobsen, E. (2012) Functional Stacking of Three Resistance Genes against Phytophthora infestans in Potato. Transgenic Research, 21, 89-99. https://doi.org/10.1007/s11248-011-9510-1 
[28] Rietman, H., Bijsterbosch, G., Cano, L.M., Lee, H.-R., Vossen, J.H., Jacobsen, E., Visser, R.G.F., Kamoun, S. and Vleeshouwers, V.G.A.A. (2012) Qualitative and Quantitative Late Blight Resistance in the Potato Cultivar Sarpo Mira Is Determined by the Perception of Five Distinct RXLR Effectors. Molecular Plant-Microbe Interactions, 25, 910-919. https://doi.org/10.1094/MPMI-01-12-0010-R

[29] Halterman, D.A., Kramer, L.C., Wielgus, S. and Jiang, J.M. (2008) Performance of Transgenic Potato Containing the Late Blight Resistance Gene RB. Plant Disease, 92, 339-343. https://doi.org/10.1094/PDIS-92-3-0339

[30] Michalska, A.M., Zimnoch-Guzowska, E., Subkowiak, S. and Plich, J. (2011) Resistance of Potato to Stem Infection by Phytophthora infestans and a Comparison to Detached Leaflet and Field Resistance Assessments. American Journal of Potato Research, 88, 367-373. https://doi.org/10.1007/s12230-011-9202-7

[31] Orłowska, E., Fiil, A., Kirk, H.-G., Llorente, B. and Cvitanich, C. (2012) Differential Gene Induction in Resistant and Susceptible Potato Cultivars at Early Stages of Infection by Phytophthora infestans. Plant Cell Reports, 31, 187-203. https://doi.org/10.1007/s00299-011-1155-2

[32] Park, T.H., Vleeshouwers, V., Kim, J.B., Hutten, R.C.B. and Visser, R.G.F. (2005) Dissection of Foliage and Tuber Late Blight Resistance in Mapping Populations of Potato. Euphytica, 143, 75-83. https://doi.org/10.1007/s10681-005-2658-0

[33] Bradshaw, J.E., Hackett, C.A., Lowe, R., McLean, K., Stewart, H.E. and Tierney, I. (2006) Detection of a Quantitative Trait Locus for Both Foliage and Tuber Resistance to Late Blight [Phytophthora infestans (Mont.) de Bary] on Chromosome 4 of a Dihaploid Potato Clone (Solanum tuberosum subsp tuberosum). Theoretical and Applied Genetics, 113, 943-951. https://doi.org/10.1007/s00122-006-0353-8

[34] Platt, H.W. and Tai, G.H. (1998) Relationship between Resistance to Late Blight in Potato Foliage and Tubers of Cultivars and Breeding Selections with Different Resistance Levels. American Journal of Potato Research, 75, 173-178. https://doi.org/10.1007/BF02853569

[35] Stewart, H.E., Bradshaw, J.E. and Wastie, R.L. (1994) Correlation between Resistance to Late Blight in Foliage and Tubers in Potato Clones from Parents of Contrasting Resistance. Potato Research, 37, 429-434. https://doi.org/10.1007/BF02358357

[36] Kirk, W.W., Felcher, K.J., Douches, D.S., Niemira, B.A. and Hammerschmidt, R. (2001) Susceptibility of Potato (Solanum tuberosum L.) Foliage and Tubers to the US8 Genotype of Phytophthora infestans. American Journal of Potato Research, 78, 319-322. https://doi.org/10.1007/BF02875697

[37] Stewart, H.E., Wastie, R.L., Bradshaw, J.E. and Brown, J. (1992) Inheritance of Resistance to Late Blight in Foliage and Tubers of Progenies from Parents Differing in Resistance. Potato Research, 35, 313-319. https://doi.org/10.1007/BF02357712 


\section{Supplementary Figure}

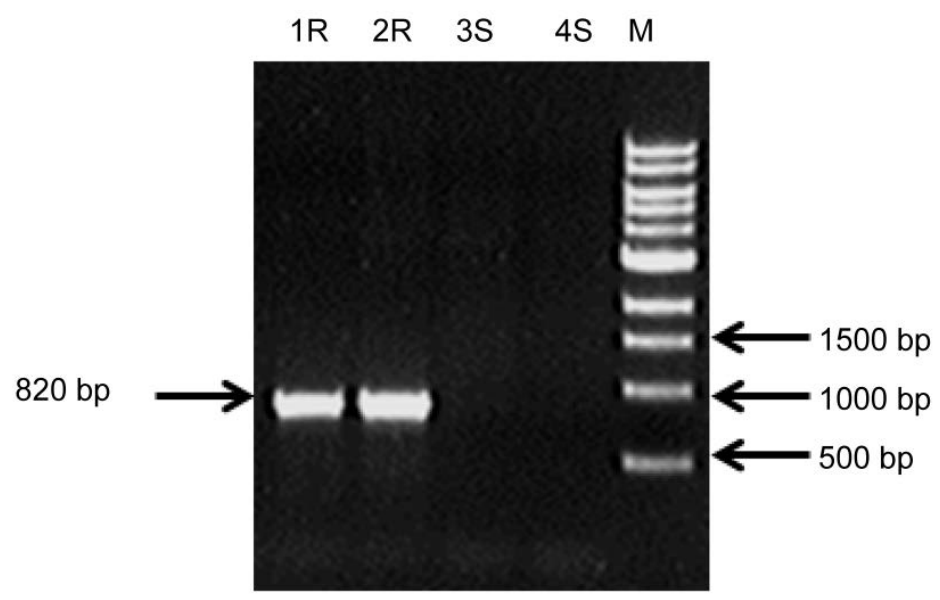

Figure S1. Agarose gel electrophoresis showing the PCR products of Marker 1 BLB1F/BLB1R.1R and 2R are the resistant parents of F02005, F02006; 3S and 4S are the susceptible parents of Prospect and PR90-50-32. M is a DNA ladder (New England Biolabs).

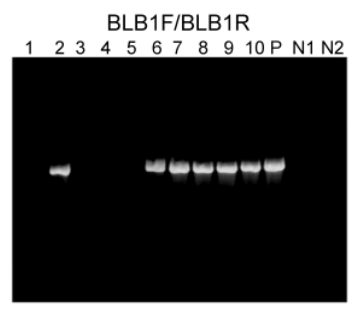

BLB1F/BLB1R
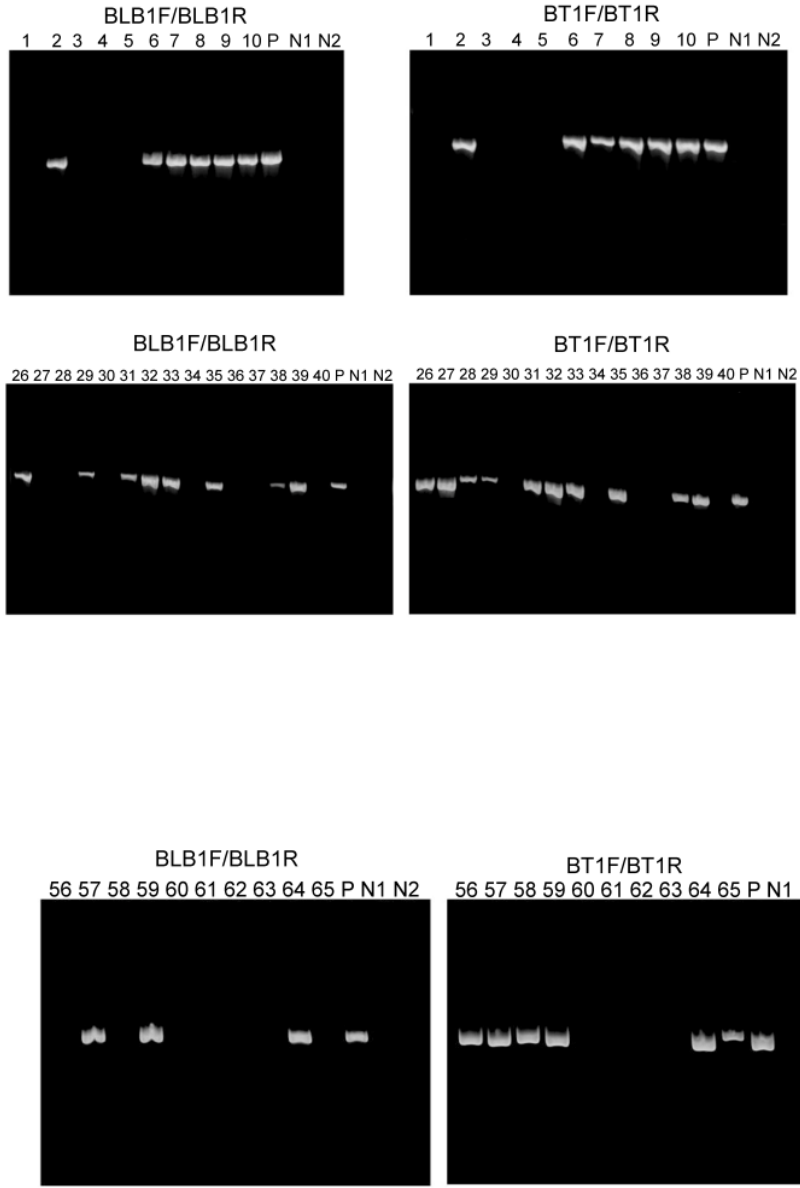

BT1F/BT1R
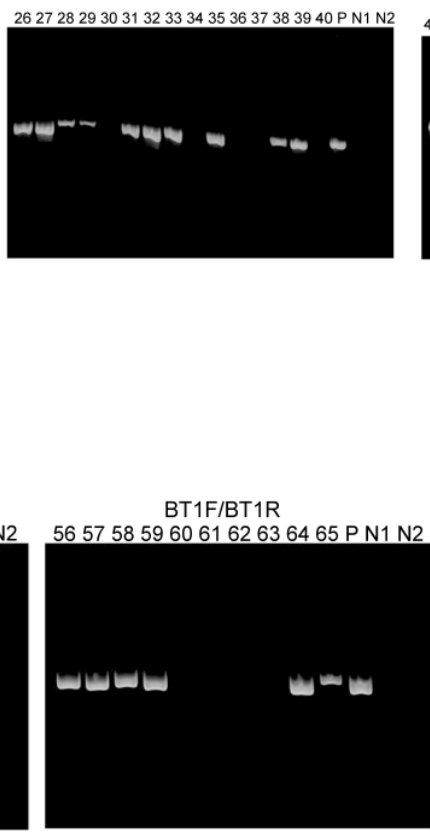

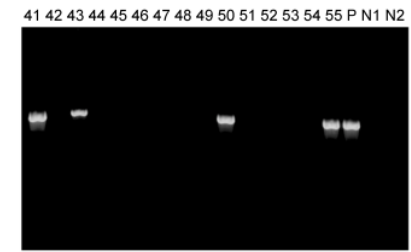

BLB1F/BLB1R
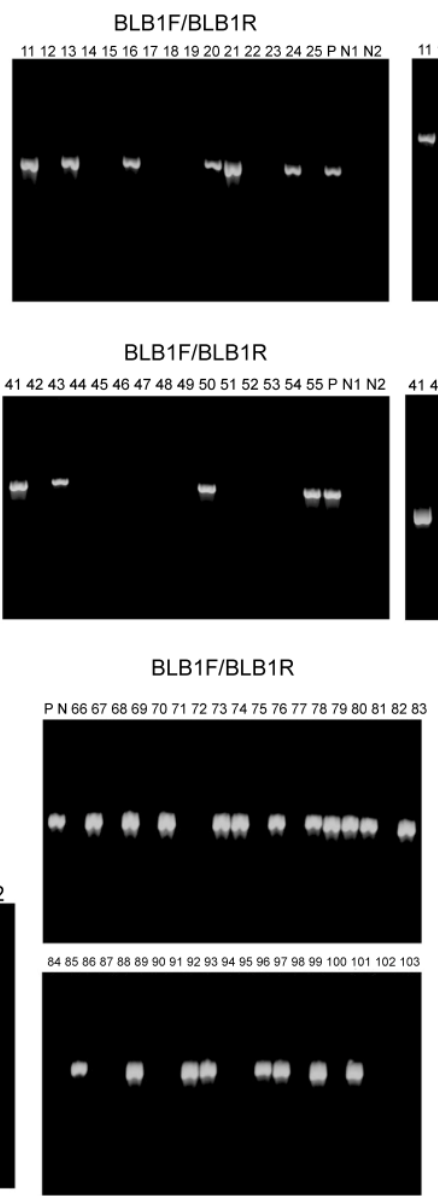

BLB1F/BLB1R

BT1F/BT1R

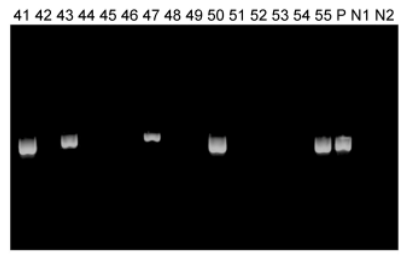

BT1F/BT1R

N 666768697071727374757677787980818283



44858687888990919293949596979899100101102103

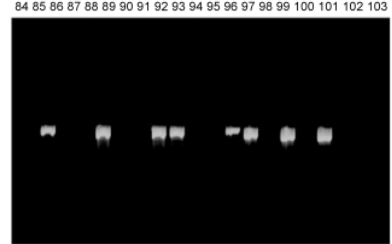

Figure S2. PCR products using Marker 1 (BLB1F/BLB1R) and Marker 22 (BT1F/BT1R) of 100 progeny tested on 0.8\% agarose gels. Specific bands of 820 bp and 729 bp were identified using Marker 1 and Marker 22, respectively. P: Positive control (a resistant parent), N1 and N: Negative controls (a susceptible parent), N2: Negative control $\left(\mathrm{ddH}_{2} \mathrm{O}\right)$. 
Submit or recommend next manuscript to SCIRP and we will provide best service for you:

Accepting pre-submission inquiries through Email, Facebook, LinkedIn, Twitter, etc. A wide selection of journals (inclusive of 9 subjects, more than 200 journals)

Providing 24-hour high-quality service

User-friendly online submission system

Fair and swift peer-review system

Efficient typesetting and proofreading procedure

Display of the result of downloads and visits, as well as the number of cited articles Maximum dissemination of your research work

Submit your manuscript at: http://papersubmission.scirp.org/

Or contact ajps@scirp.org 